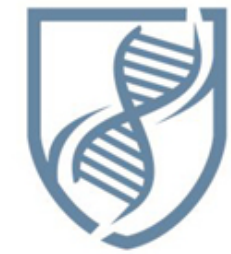

Journal of Bioscience and Applied Research
JBAAR

WWW.JBAAR.ORG

\title{
Biological activity of four plant oils, against the red palm weevil, Rhynchophorus ferrugineus (Oliver), (Coleoptera: Curculionidae)
}

\author{
Ahmed F. A.; Hussein K.T. and Gad M.I \\ Zoology Department, Faculty of Science, Zagazig University, Egypt
}

\begin{abstract}
In the present study, four botanical oils of Melissa officinalis, Borago officinalis, Laurus nobilis and Carapichea ipecacuanha were tested against newly emerged adult males and females of the red palm weevil, Rhynchophorus ferrugineus (Oliver) for investigating their insecticidal activity, their effects on some bilogical aspects and morphogenetic abnormalities in the all stages.The results revealed that the males of Rhynchophorus ferrugineus were more susceptible to the four botanical oils than the females, followed by the immature larvae. The larvae showed different degrees of susceptibility to the four botanical oils, they showed the highest susceptibility to $C$. ipecacuanha and the lowest to B. officinalis oil at $\mathrm{LC}_{50}$ levels. Both adult males and females showed the highest susceptibility to $C$. ipecacuanha and the lowest to L. nobilis oil at $\mathrm{LC}_{50}$ levels. Also, the obtained results showed that the four tested oils disrupted some biological aspects of the tested insects. These oils markedly reduced male and female longevity, female fecundity and hatchability of the laid eggs. Morphogenetic abnormalities such as darkness of pupae, incomplete adult eclusion , dwarfism and crumpled wings and legs of adults appeared in the different stages of the insect as a result of treatment with the four tested oils.
\end{abstract}

\section{Introduction}

The date palm, Phoenix dactylifera (Linn.), is the most important fruit crop in the Middle East. Date palm trees are liable to be attacked by many insect pests which cause serious damages to the different parts of the tree. The most serious insect pest namely, the red palm weevil, Rhynchophorus ferrugineus (Oliver) was first recorded in date palm plantations of Sharkia and Ismailia Governorates in Egypt by Saleh (1992).

Essential oils proved potential sources of alternative compounds to currently used fumigants. These oils have low toxicity to warm-blooded animals, high volatility and toxicity to stored-grain pests and weevils (Regnault-Roger and Hamraoui ,1995; Regnault-Roger, ,1997 and Shaaya et al. 1997).

Various chemical organic compounds have been isolated from plants, they include fixed oils, volatile oils and other plant constituents which expressed potential action against insect species. Extraction, isolation and identification of the fixed oils have been extensively studied by many authors (Abdallah et al. 1986; Moustafa et al. 1986; Baraka and EL-Hady 1993; Hussein and Shoukry, 1997; Shoukry Karima, 2003). El-Sayed et al. (1989) found that maize oil and coconut oil when used against Callosobruchus maculatus reduced the progeny. Abdel-Kawy and Gharib (1991) stated that oils of cotton seeds, sesame and peanut showed efficiency in treatment of yellow meal corn against the rice weevil, Sitophilus oryzae (L.).Jood et al. (1993) used neem (Azadirachta indica) oil, powders of neem leaf and neem kernel, Citrus limon leaf, Allium sativum, Mentha spichata leaf in wheat grains at levels of $1 \%$ and $2 \%(\mathrm{w} / \mathrm{w})$ against larvae of Trogoderma granarium Everts and they found that neem products completely prevented damage by an introduced larval populations. Adult emergence of $C$. macculatus was completely inhibited by castor oil, black seed oil and olive oil at concentration of $1 \%$ for 30 days (Swidan, 1996). Also, the essential oils were tested against many insect species (Bouda et al., 2001; Isikber et al., 2006).

The volatile oils of Boxus chinensis against 10 days-old larvae of the $R$. ferrugineus showed toxicological and pathological effects (Abdullah,2009).Huseyin et al., (2006) noticed that ethanolic extracts of some aerial parts of lamiaceae species showed high larvicidal activity after 24 
hours and M. officinalis (Linn.) oil was the highest toxic against larvae of Culex pipiens Linn. Karahroodi-Zahra et al., (2011) investigated fumigant toxicity of six essential oils from M. officinalis (L.), Mentha piperata (L.), Petroselinum sativum (Hoffman), Lavendula angustifolia (Mill.), Ziziphora clinopodioides (Lam.), and Artemisia dracunculus (L.), on first instar larvae and eggs of Plodia interpunctella Hübner, they found that $M$. officinalis recorded moderate ovicidal activity. Ben Jemâa et al., (2011) studied the chemical composition and the repellent activity of Laurus nobilis essential oil against 7-10 days old-adults of the cigarette beetle, Lasioderma serricorne. They concluded that repellent action was highly dependent upon oil concentration and exposure time and L.nobilis essential oil may have potential as a control agent against this beetle. The essential oil of B. officinalis (L.) showed good larvicidal potential after $48 \mathrm{hrs}$ of exposure period against Anopheles gambiae (Kweka et al., 2012). Essential oil of L. nobilis showed strong fumigant toxicity against Trogoderma granarium larvae (Tayoub et al., 2012).The ability of the aggregation pheromone to capture more females than males RPWs in the traps which makes trapping a potential tool for managing $R$. ferrugineus (ElBokl et al., 2015)

Morphogenetic abnormalities appeared in Synthesiomyia nudiseta stages including larval-pupal intermediate, deformed adults with crumpled wings or deformed thorax and abdomen when treated with the volatile botanical oil of Cupressusma crocarpa and Alpina officinarum (khalaf et al., 2009).Powder of four plants, B. officinalis; M. piperta; Officinalis anisum; Eucalyptus glubulus was tested by Farman-Khansaa, (2009) against the red flour beetle, Tribolium castaneum and he found that $M$. piperta had most repellent efficiency plant, followed by $O$. anisum, $E$. glubulus, While the lowest was B. officinalis. In the present study, four botanical oils of Melissa officinalis, Borago officinalis, Laurus nobilis and Carapichea ipecacuanha were tested against newly emerged adult males and females of the red palm weevil, Rhynchophorus ferrugineus (Oliver) for investigating their insecticidal activity, their effects on some bilogical aspects and morphogenetic abnormalities in the all stages.

\section{Materials and methods}

\section{The test insect:}

Adult red palm weevils , $R$. ferrugineus were obtained from coccons collected from infested date palm trees in Sharkia and Dakahlia Governorates, incubated in an oblongate trans- parent plastic boxes $(120 \times 60 \times 30 \mathrm{~cm})$ with easily removable perforated covers. These coccons were kept in wet toweling till adult emergence. The newly emerged adults were sexually differentiated and fed on small pieces of red palm core.

\section{Tested plants:}

The plants under investigation were originally obtained from local and international markets, identified, divided into two groups $\mathrm{A}$ and $\mathrm{B}$, according to their constituents (fixed or volatile oils), these plants are listed in table (1)

Table (1): The tested plants.

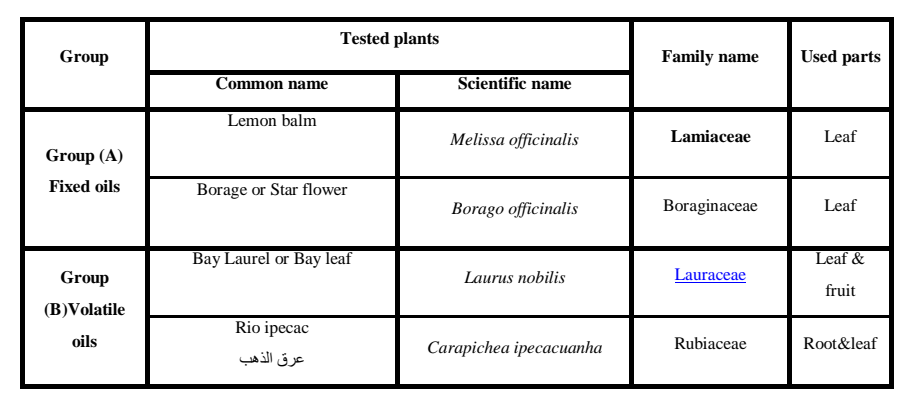

\section{Extraction of oils:}

Extraction of the fixed oils was performed from crushed and previously steam distilled plant parts of group A, where the dry powdered plants were macerated in petroleumether (40/60) according to Harbourne, (1984) and El-Sayed et al., (1989). The petroleum- ether extracts were filtered through anhydrous sodium sulphate. The solvent was removed by using rotary evaporator and the oils were stored under nitrogen gas until use.

The volatile oils were extracted from different parts of plants represented in table (1) group B, by using steam distillation technique according to the method of Anderson et al., (1980). Then oils were saturated with sodium chloride and extracted again with diethyl ether the extracts were dried over anhydrous sodium sulphate and evaporated under reduced pressure by using rotary evaporator apparatus.

\section{Test method:}

Serial concentrations of aqueous solution of the two groups of oils were prepared and $(0.1 \%$ tween was added to the fixed oil as an emulsifier). Small pieces of date palm hearts were rinsed in each concentration for 20 seconds, then left to dry at room temperature. Treated pieces were put separately in all replicates of pairs of newly emerged adults or 10 days-old larvae of the second generation. For each concentration individuals of adults were counted after 10 days and after 7 days for larvae post treatments under laboratory conditions $\left(30{ }^{\circ} \mathrm{C} ., 75 \pm 5 \%\right.$ R.H., and 12D : 12 $\mathrm{L}$ hrs.) to determine the mortality percentage . Toxicity lines were established and $\mathrm{LC}_{50}$ values were determined. The Toxicity lines were analyzed according to the method described by Finney (1952). The slope function and the relative potency of the tested oils were determined according to Sun (1950).

\section{Results}

Results in table (2) revealed that the C. ipecacuanha was the highest toxic to the larvae $\left(\mathrm{LC}_{50}=1264.09 \mathrm{ppm}\right)$, followed by $L$. nobilis oil $\left(\mathrm{LC}_{50}=2424.32\right)$ and then $B$. officinals $\left(\mathrm{LC}_{50}=2518.91 \mathrm{ppm}\right)$. The relative potencies based on C. ipecacuanha were 1.26,1.99 and 1.91 for $M$. 
officinals, B. officinals and L. nobilis, respectively. The relatively low values of slope functions revealed

Also, the results in Table (2), showed that, the highest toxicity to the adult male weevil was satisfied to C.ipecacuanha $\left(\mathrm{LC}_{50}=878.72 \mathrm{ppm}\right)$ followed by $M$. officinalis, $B$. officinalisoil then $L$. nobilis. The relative potencies of oils based on C. ipecacuanha oil were 1.29, 1.43 and 2.00 for $M$. officinalis, B. officinalis and $L$. nobilis, respectively. The relatively low values of slope functions revealed the homogenous response of the tested stages to the different concentrations of the tested oils.

Table (2): Toxicity and the Relative potency of the fixed and volatile oils against $\boldsymbol{R}$. ferrugineus

\begin{tabular}{|c|c|c|c|c|}
\hline \multicolumn{5}{|c|}{10 days-old larvae: } \\
\hline 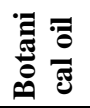 & Tested plant & $\begin{array}{c}\mathbf{L C}_{50}(\mathbf{p p m}) \\
\text { (Confidence limits) }\end{array}$ & $\begin{array}{c}\text { Slope } \\
\text { function }\end{array}$ & $\begin{array}{l}\text { Relative } \\
\text { potency }\end{array}$ \\
\hline \multirow{2}{*}{ 赵 } & Lemon balm (Melissa officinalis) & $\begin{array}{c}1604.642 \\
(1279.837-2013.157)\end{array}$ & 2.335 & 1.269 \\
\hline & Borage (Borago officinalis) & $\begin{array}{c}2518.913 \\
(2387.994-2657.587)\end{array}$ & 4.602 & 1.993 \\
\hline \multirow{2}{*}{$\stackrel{\frac{0}{0}}{\frac{\pi}{0}}$} & Bay leaf (Laurus nobilis) & $\begin{array}{c}2424.323 \\
(2298.722-2544.902) \\
\end{array}$ & 5.253 & 1.918 \\
\hline & Rio ipecac (Carapichea ipecacuanha) & $\begin{array}{c}1264.097 \\
(1035.893-1517.927)\end{array}$ & 2.571 & 1 \\
\hline \multicolumn{5}{|c|}{ Adult females: } \\
\hline \multirow{2}{*}{ 总 } & Lemon balm (Melissa officinalis) & $\begin{array}{c}1290.569 \\
(1144.586-1464.315)\end{array}$ & 2.022 & 1.207 \\
\hline & Borage (Borago officinalis) & $\begin{array}{c}1370.219 \\
(1234.519-1509.268)\end{array}$ & 2.595 & 1.281 \\
\hline \multirow{2}{*}{$\stackrel{0}{0}_{\frac{0}{0}}^{\frac{0}{0}}$} & Bay leaf (Laurus nobilis) & $\begin{array}{c}1899.779 \\
(1783.881-2014.539)\end{array}$ & 4.452 & 1.776 \\
\hline & Rio ipecac (Carapichea ipecacuanha) & $\begin{array}{c}1069.534 \\
(970.822-1179.14)\end{array}$ & 2.477 & 1 \\
\hline \multicolumn{5}{|c|}{ Adult males: } \\
\hline \multirow{2}{*}{ 总 } & Lemon balm (Melissa officinalis) & $\begin{array}{c}1140.85 \\
(1033.766-1262.715)\end{array}$ & 2.409 & 1.298 \\
\hline & Borage (Borago officinalis) & $\begin{array}{c}1259.165 \\
(977.057-1528.304)\end{array}$ & 3.175 & 1.433 \\
\hline \multirow{2}{*}{ 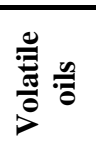 } & Bay leaf (Laurus nobilis) & $\begin{array}{c}1758.669 \\
(1449.213-2033.129)\end{array}$ & 4.436 & 2.001 \\
\hline & Rio ipecac (Carapichea ipecacuanha) & $\begin{array}{c}878.728 \\
(783.846-979.989)\end{array}$ & 2.132 & 1 \\
\hline
\end{tabular}

Data in table (3) showed a highly significant decrease in Data in table (4) showed that, there was significant increase both male and female longevity of $R$. ferrugineus when in larval duration in case of treatment with the volatile oils treated with the plant oils of M.officinalis and B.officinalis as fixed oils; L.nobilis and C. ipecacuanha as volatile oils.

Also, the treatment with the tested plant oils of $M$. officinalis, B. officinalis, C. ipecacuanha and L. nbilis showed a high significant reduction on the fecundity.

Hatching percentage of eggs laid by adult females treated with the all tested oils decreased high significantly. The hatching percentages were $57.8 \pm 0.25 \%$ and $64.17 \pm 0.64 \%$ in case of treatment with $C$. ipecacuanha, and $L$. nobilis volatile oils, respectively. While the hatching percentages in case of treatment with the two fixed oils reached $59.8 \pm 0.2 \%$ in $M$. officinalis and $61.09 \pm 0.29 \%$ in $B$. officinalis oil. while statistical analysis of the decrease in the larval duration in case of treatment with the two fixed oils of $M$. officinalis and B. officinalis was not significant.

Significant increase in prepupal and pupal durations occurred by the treatment with $C$. ipecacuanha as it reached $7.2 \pm 0.88$ and $11.85 \pm 1.12$ days, respectively. While treatment with fixed oils of M. officinalis and B. officinalis decreased non significantly in the prepupal and pupal durations.

High significant reduction in the pupation percentage of treated larvae reached $42.33 \pm 0.33 \%$ by $C$. ipecacuanha, $56.12 \pm 2.6 \%$ by M. officinalis, $60.7 \pm 1.82 \%$ by $B$. officinalis, 
Table (3): Effect of $\left(\mathrm{LC}_{50 \mathrm{~s}}\right)$ of plant oils on biological aspects of newly emerged adults of $R$. ferrugineus

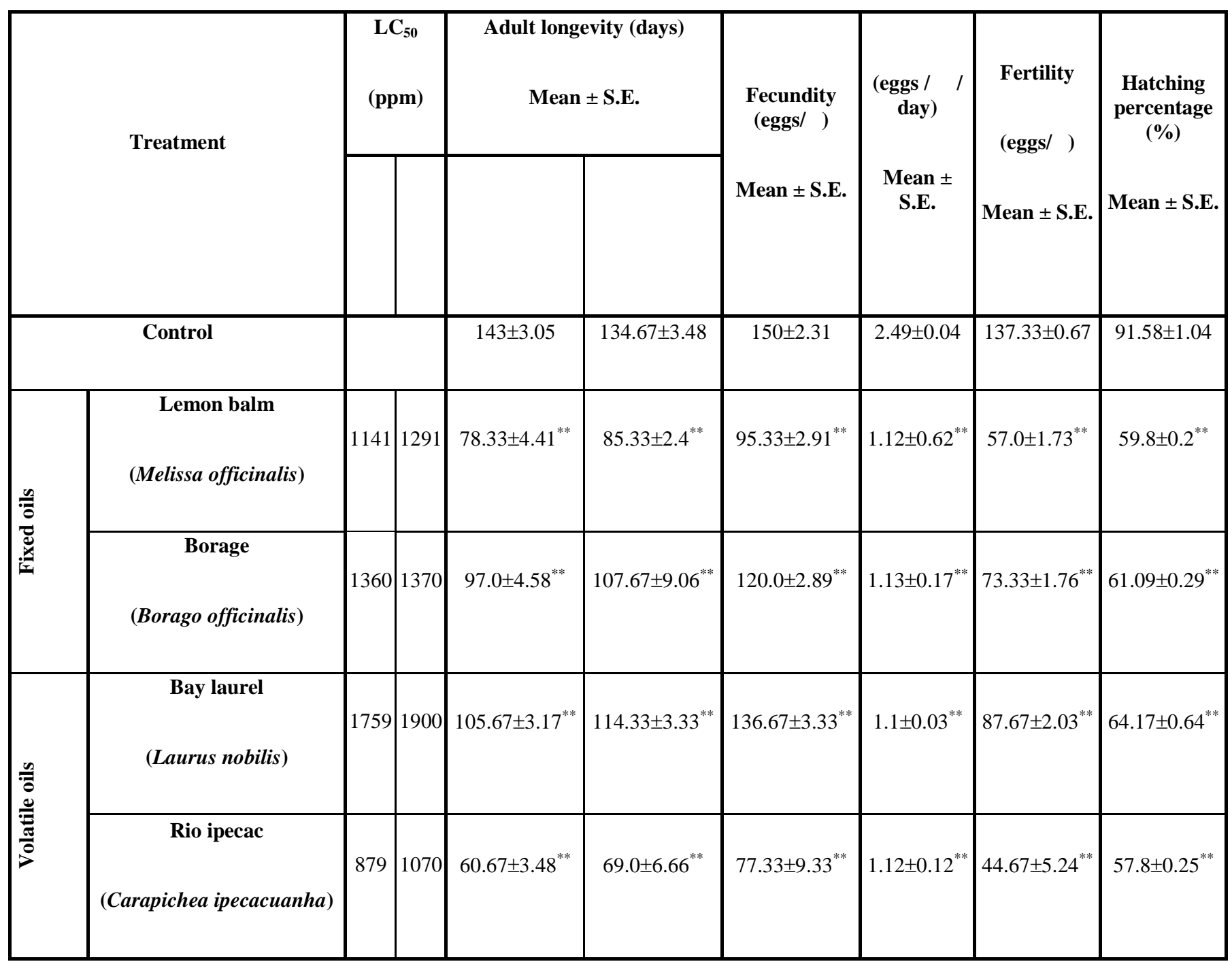

Without * Non significant $(\mathrm{P}>0.05) . *$ Significant $(\mathrm{P}<0.05) . \quad * *$ highly significant $(\mathrm{P}<0.001)$

Also, the data in table (4) showed non-significant decrease and $61.22 \pm 2.4 \%$ by $L$. nobilis, while that, of control was $91.0 \pm 0.0 \%$.

The treatment of 10 days old-larvae with $\left(\mathrm{LC}_{50}\right)$ of the two plant oils (fixed and volatile)resulted in high significant reduction of adult emergence (\%).

Both male and female longevity also decreased significantly when treated by the two fixed and volatile oils and showed high significant decrease in their duration when treated with $C$. ipecacuanha. The tested plant oils had variable effects on fecundity of females emerged from treated larvae. The mean number of eggs deposited by a female decreased high significantly in case of treatment with $C$. ipecacuanha oil and was non-significant in case of treatment with M. officinalis, B. officinalis and L. nobilis. in hatching $(\%)$ of eggs laid by females emerged from treated larvae except that, of C.ipecacuanha, which showed a significant decrease. It was clear that, the plant oils (both the fixed and volatile) seriously disrupted some biological aspects of $R$. ferrugineus (Oliver).

Effect of plant extracts on the morphogenetic

abnormalities:

Treatment of $R$. ferrugineus larvae with the tested plant oils resulted in pupae with various morphogenetic abnormalities. These abnormalities were represented by darkening of the pupae which differed from the normal pupae as shown in Fig (1). Almost of abnormal pupae died inside the cocoon, failed to emerge and changed to incomplete adult. 
Table (4): Effect of $\left(\mathrm{LC}_{50 \mathrm{~s}}\right)$ of plant oils on different biological aspects of 10 days - old larvae of $R$. ferrugineus

\begin{tabular}{|c|c|c|c|c|c|c|c|c|c|c|c|}
\hline \multirow{2}{*}{\multicolumn{2}{|c|}{ }} & \multirow{2}{*}{ 言 } & \multirow{2}{*}{ 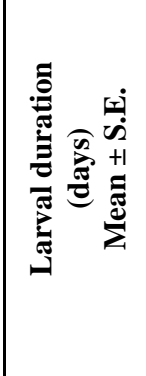 } & \multicolumn{4}{|c|}{ Pupal stage } & \multicolumn{2}{|c|}{$\begin{array}{l}\text { Adult Longevity } \\
\text { (days) } \\
\text { Mean } \pm \text { S.E. }\end{array}$} & \multirow{2}{*}{ 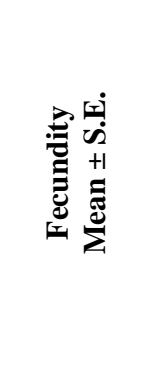 } & \multirow{2}{*}{ 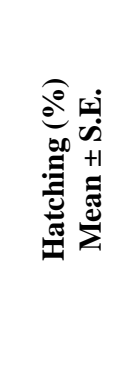 } \\
\hline & & & & $\begin{array}{c}\text { Prepupal } \\
\text { Duration } \\
\text { (days) } \\
\text { Mean } \pm \\
\text { S.E. }\end{array}$ & $\begin{array}{c}\text { Pupal } \\
\text { Duration } \\
\text { (days) } \\
\text { Mean } \pm \\
\text { S.E. }\end{array}$ & $\begin{array}{c}\text { pupation } \\
(\%)\end{array}$ & $\begin{array}{l}\text { Adult } \\
\text { emergence } \\
(\%)\end{array}$ & $0^{*}$ & 우 & & \\
\hline & Control & & $\begin{array}{c}45.67 \pm 2.3 \\
3\end{array}$ & $5.0 \pm 0.58$ & $\begin{array}{c}8.67 \pm 0.3 \\
3\end{array}$ & $91.0 \pm 0.0$ & $85.0 \pm 0.33$ & $143 \pm 3.05$ & $\begin{array}{c}134.67 \pm 3.4 \\
8\end{array}$ & $150 \pm 2.31$ & $\begin{array}{c}91.58 \pm 1.0 \\
4\end{array}$ \\
\hline \multirow{2}{*}{ 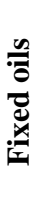 } & $\begin{array}{c}\text { (Melissa } \\
\text { officinalis) }\end{array}$ & 1605 & $38.4 \pm 1.8$ & $3.8 \pm 0.24^{*}$ & $7.8 \pm 0.33$ & $\begin{array}{c}56.12 \pm 2 \\
6^{* *}\end{array}$ & $55.12 \pm 3.2^{* *}$ & $\begin{array}{c}97.24 \pm 3.6 \\
8^{* * *}\end{array}$ & $109.28 \pm 2.1^{*}$ & $\begin{array}{c}120.12 \pm 2.1 \\
1^{*}\end{array}$ & $79.2 \pm 0.67$ \\
\hline & $\begin{array}{c}\text { (Borago } \\
\text { officinalis) }\end{array}$ & 2519 & $40.5 \pm 2.6$ & $4.5 \pm 0.67$ & $8.0 \pm 0.25$ & $\begin{array}{c}60.7 \pm 1.8 \\
2^{* *}\end{array}$ & $\underset{* * *}{62.67 \pm 0.67}$ & $\begin{array}{c}118.23 \pm 2 . \\
33^{*}\end{array}$ & $124.24 \pm 1.8$ & $137.28 \pm 2.8$ & $\begin{array}{c}85.17 \pm 0.6 \\
4\end{array}$ \\
\hline \multirow{2}{*}{ 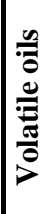 } & $\begin{array}{l}\text { (Laurus } \\
\text { nobilis) }\end{array}$ & 2424 & $\begin{array}{c}56.33 \pm 2.1 \\
4^{*}\end{array}$ & $5.5 \pm 0.33$ & $\begin{array}{c}9.45 \pm 0.8 \\
5\end{array}$ & $\begin{array}{c}61.22 \pm 2 \\
4^{* * *}\end{array}$ & $66.67 \pm 2.28$ & $\begin{array}{c}125.67 \pm 2 . \\
14^{*}\end{array}$ & $\begin{array}{c}127.33 \pm 2.3 \\
3\end{array}$ & $\begin{array}{c}142.67 \pm 2.3 \\
3\end{array}$ & $\begin{array}{c}87.12 \pm 0.2 \\
9\end{array}$ \\
\hline & $\begin{array}{c}\text { (Carapichea } \\
\text { ipecacuanha) }\end{array}$ & 1264 & $68.0 \pm 3.21^{*}$ & $7.2 \pm 0.88^{*}$ & $\begin{array}{c}11.85 \pm 1 \\
12^{*}\end{array}$ & $\begin{array}{c}42.33 \pm 0 . \\
33^{* *}\end{array}$ & $50.52 \pm 1.02$ & $80.0 \pm 5.12$ & $89.0 \pm 4.66^{* *}$ & $\begin{array}{c}100.67 \pm 3.6 \\
7^{* * *}\end{array}$ & $75.8 \pm 0.25$ \\
\hline
\end{tabular}

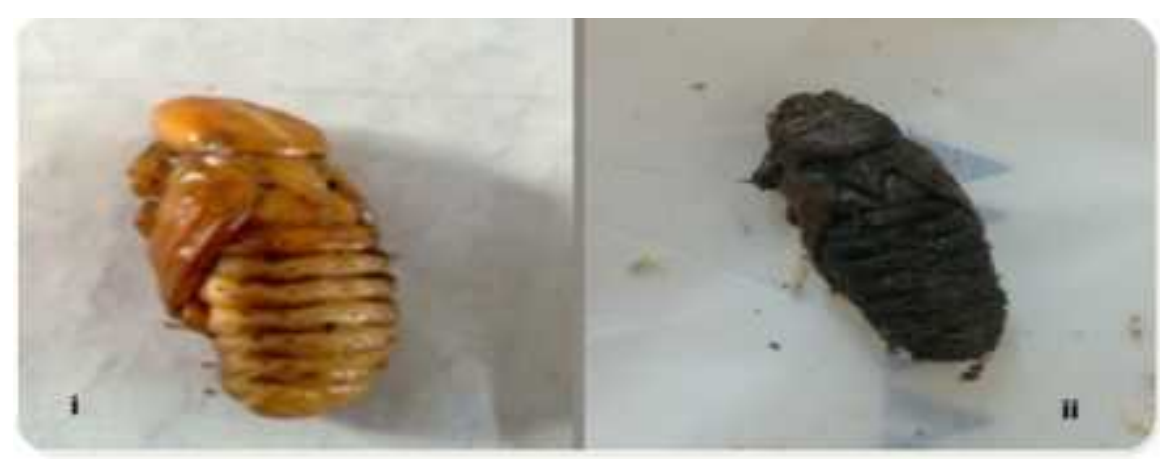

Fig. (1)Pupal deformation,

i- $\quad$ Normal pupa of Rhynchophorus ferrugineus

ii- Pigmentation of pupa due to volatile and fixed oil treatment 


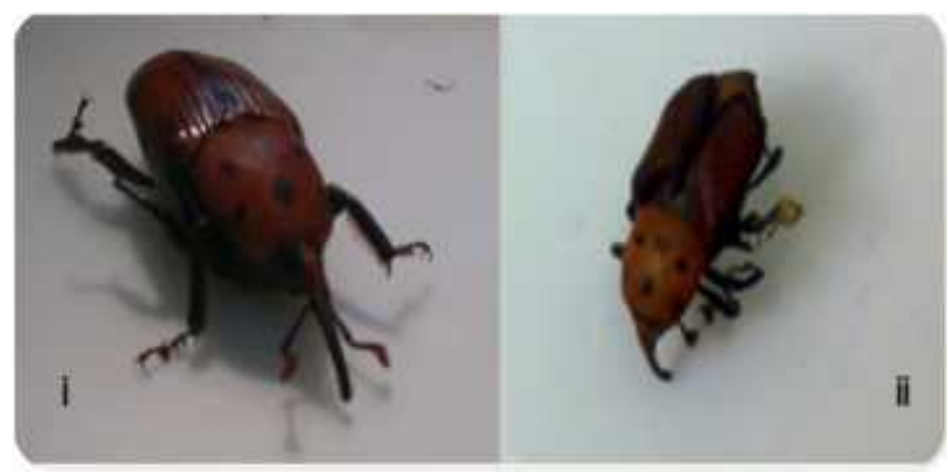

Fig. (2) Adult deformation,

i.Normal adult of Rhynchophorus ferrugineus

ii-Adult dwarfism due to volatile and fixed oil treatment

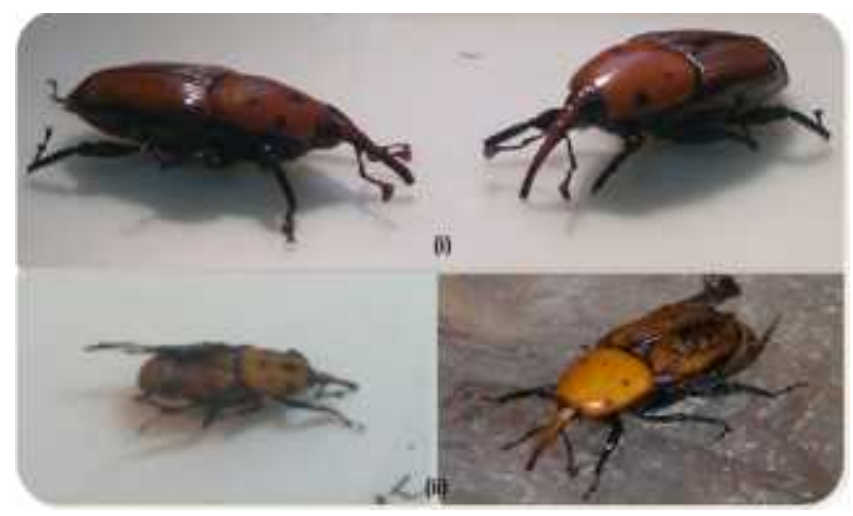

Fig. (3) Adult deformation,

i- $\quad$ Normal adult of Rhynchophorus ferrugineus

ii- Deformed adult with crumpled legs and wings due to volatile and fixed oil treatments

\section{Discussion}

From ecological point of view, insecticides of plant origin proved efficient, biodegradable as well as suitable alternative for palm weevils control. The control methods should aim at the weakest link of the life cycle of the weevil, which is the larval stage. The pest control methods were directed to the use of insecticides of plant origin. Plants are rich sources of bioactive compounds and offer an advantage over synthetic insecticides as are less prone to development of resistance, easily biodegradable and less toxic to natural environment. In fact many researchers have reported that essential oils of different plant extract having good larvicidal potentiality (Lee et al. 2001, Kotan et al. 2008, Koul et al, 2008).

Essential oils from various plants have shown promise as sources for insecticides. Earlier attempts to explore the toxicity of plant derivatives against $R$. ferrugineus have been made by essential oils. Nassar and Abdullah (2005) tested two natural insecticides, Boxus chinensis oil and precocene II topically against larvae, prepupae and adult of red palm weevil, R. ferrugineus and the larvae of the palm beetle, pseudophilus testsceous. They found that larvae of $R$. ferrugineus were less tolerant to $B$. chinensis oil and more tolerant to precocene II than palm beetle larvae. Huseyin et al. (2006) studied the larvicidal activity of ethanolic extracts of some arial parts of Lamiaceae species against Culex pipiens (Linn.). They found that all plant extracts showed strong larvicidal activity after 24 hours exposure tests. Melissa officinalis (Linn.) oil showed the highest toxic activity. Abdullah (2009) tested the volatile oil of Boxus chinensis against 10-days old larvae of the red palm weevil, $R$. ferrugineus. He found that it had toxicological and pathological effects on $R$. ferrugineus larvae.

The present study revealed that the toxicity of the four botanical oils to the 10 days- old larvae and adults of $R$. ferrugineus showed that the (C. ipecacuanha) oil was superior to the other three oils of lemon palm $(M$. officinalis), Bay leaf (L. nobilis) and the borage (B. 
officinalis) oils, while Borage showed the least toxic oil. The variation in the toxicological effects of the tested oils might be due to differences in their chemical composition as well as the variation in sensitivity and response to the various cells and tissues. This might also be depending on the amount of poison that reach the site of action. Mostafa et al. (1995) reported that the volatile oils of some plants increased the activity of Malic Dehydrogenase Enzyme (MDE) and decreased the activity of ( Malic Enzyme) (ME) in Pectinophora gossypiella and Erias insulana larvae.

From the above mentioned data we concluded that the two fixed and the two volatile oils caused a similar significant decrease in both male and female longevities. This result agreed with Andronikashvili and Reichmuth (2003) who indicated that, the volatile oil of L. nobilis had high repellency effect towards adult of red flour beetle, Tribolium castaneum explaining its moderate insecticidal activity and reducing periods of male and female longevity. Similar results were obtained by Isikber et al. (2006). FarmanKhansaa (2009) investigated the repellent effect of powder of four plants; $B$. officinalis, $M$. piperta, $O$. anisum and Eucaluptus glubulus against the red flour beetles Tribolium castanium, reflecting the first essential reason of weevil longevities decrease, which is due to their high repellency.The same high repellency was recorded by Ben Jemâa et al. (2011) against adults of the cigarette beetle Lasioderma serricorne, also led to decrease in adult longevity. Also Mohamad et al.( 2011) studied the causes of attraction and repellency effect of some plants extracts from leaves and roots of Borago and Tages plant against the Southern cowpea weevil, $C$. maculates (Fab.) and showed a significant differences in attraction and repellency effect according to the kind of extracted plant and concentration. When repellency occurs, it refers to the major reason of dramatical weevil longevity decrease. The same result was achieved by the volatile oil and this is agreed with KarahroodiZahra et al. (2009) who showed that, the volatile oils of $M$. officinalis had a moderate repellency against adults of $P$. interpunctella reflecting the first essential reason of weevil longevities decrease.

Also, the present study revealed that both fixed and volatile oils caused a significant decrease in both male and female longevities, a result confirmed by Andronikashvili and Reichmuth (2003) who indicated that, the volatile oil of $L$. nobilis had high repellency effect towards adult of red flour beetle, T. Castaneum. Similar results were obtained by Isikber et al. (2006).

The present study revealed that, fixed oils markedly decreased the average number of eggs deposited by treated females. This was confirmed by the findings of Schoonhoven (1978) and Shankaranarayana et al. (1979). Singh et al (1978) mentioned that, groundnut oil prevented the emergence of progeny rather than affecting the oviposition of $C$. maculates. Abdel-Kawy and Gharib (1991) indicated that, cotton seed oil, sesame, peanut and paraffin oils reduced the number of progeny in Sitophilus oryzae. Taheya and Al-Moagel (1993) indicated that, tumeric extract reduced the khapra beetle F1 progeny, and interfered with its development. Regnault-Roger and Hamraoui (1995) showed that, the volatile oils of L.nobilis could protect kidney beans by direct or delayed insecticidal effect, through increased adult mortality and inhibition of beetle reproduction of Acanthoscelides obtectus (Say).

Also, we concluded that, the treatments by fixed and volatile oils had a significant effect on the reproductive potential of $R$. ferrugineus (Oliver). The average number of eggs laid per female as well as hatching (\%) was reduced significantly. Similar results related to the fecundity of other treated insects with volatile oils were obtained by several authors (Frik and Nazirov 1981;Dongre and Rahalkar 1982).Nassar (1995) showed that, complete sterility of Muscina stabulans adult was achieved by larval treatment with some plant extracts and Hussein (1995) reported that, treatment of the second larval instar of Parasarcophaga aegyptiaca with some volatile plant oils induced a remarkable reduction in reproductive potential of developing adults. Shoukry- Karima (2003) stated that, the tested plant volatile oils of Pipe rubebae and Sativa officinalis had a high significant decrease effect on pupation percentage, adult emergence percentage, fecundity, fertility and hatchability of females emerged from treated larvae of $P$. interpunctella.

In contrast, Singh et al. (1989) found that, volatile oils extracted from Callicarpa macrophylla and Zanthoxylum alatum plant increased the fecundity of $S$. oryzae and Sitophilus granarius. Karahroodi- Zahra et al. (2011) referred to the great toxicity of the volatile essential oils of $M$. officinalis against the first instar larvae and eggs of $P$. interpunctella leading to significant decrease in the number of hatched eggs. Karahroodi- Zahra et al. (2008) investigated fumigant toxicity of the essential oil from $M$. officinalis L. against first instar larvae and eggs, of $P$. interpunctella (Hübner) showing moderate ovicidal and egg deterrence effect against this pest. Nassar and Abdullah (2001), (2005) recorded some pupal morphogenetic abnormalities of the red palm weevil resulting in incomplete adult eclusion due to the treatment with azadirachtin and Boxus chinensis. The same result was also reported by Bream et al. (2001).

Most of the puparia failed to reach adults (aborted puparia). However, some emerged adults had various degrees of morphological abnormalities. Some individuals showed a dominance of incomplete adult eclusion, the emerged adults had some deformities varied between dorso-ventrally compressed body with collapsed appendages and complete dwarfism, Fig. (2) or with permanently expanded membranous wings, 
failed to form elytra and appearance of pits on elytra, Fig. (3).

Similar results were obtained by Gujar and Mehrota (1983) who stated that, azadirachtin applied to the last instar of Spodoptera litura had juvenilizing effect and led to the formation of larval-pupal intermediate or incomplete adult eclusion. Abahussain (1999) studied the morphological effects induced by Calotropis procera in $C$. pipiens and Anopheles multicator, abnormal forms as larval- pupal and pupal-adult intermediates appeared.

The presence of dark stain in the weevil cuticle and immature pupae formation; both were symptoms of deficiency of juvenile hormone Nassar and Abdullah (2001) or the alteration in ecdysteroid and juvenoid titers. Another conceivable suggestion is that the tested oils may have indirectly affected the release of insect ecdysteroid, by interfering with the neuroendocrine sites of release of tropic hormones, especially the prothoracicotropic hormone (Bream et al. 2001). ElBermawy and Abd el Fattah (2000) recorded that, using of plant extracts changed the protein within the fourth instar larvae of $T$. confusum which might have a biological role due to the role of DNA secreting enzymes which acted as catalyst in the metamorphosis. These studies confirm the results of present investigation related to morphogenetic effects on $R$. ferrugineus (Oliver). .

From the above mentioned data it was clear that, the plant oils, (fixed and volatile) seriously disrupted some biological aspects of $R$. ferrugineus (Oliver).

\section{References}

Abahussain, M.O. (1999).The effect of Calotropis procera(AIT) (Asclepiadacea) on Culex pipiens and Anopheles multicolor (Diptera:Culicidae). J. Egypt. Ger. Soc. Zool., 30: 205-214.

Abdalla, M.D.; Kandil, M.A. and Farag, A.A. (1986). Isolation and identification of biologically active compounds from extracts of Minteena. Barnoof and Ullaiq. Bull. Entomol.Soc. Egypt.Econ. Ser., 15: 191-197.

Abdel-Kawy, F.K. and Gharib, O.H. (1991). Treatment with different oils for the control of rice weevil, Sitophilus

oryzae(L.), in yellow meal corn. Bull. Entomol.Soc. Egypt.Econ. Ser., 19: 115-119.

Abdullah, M.A.R. (2009). Toxicological and histopathological studies of Boxus chinensis oil and precocene II on larvae of the red palm weevil, Rhynchophorus ferrugineus(Oliver) (Coleoptera :Curculionidae ). Egypt. Acad. J. biol. Sci., 2 (2): 4554.

Anderson, B.A.; Holman, R.T.; Lundgren, L. and Stenhagen, G. (1980). Capillary gas chromatogrpahy of leaf volatiles. A possible aid to breeders for pest and disease resistance. J. Agric. Food Chem., 28: 985-989.

Andronikashvili, M and Reichmuth, C. (2003). Repellency and toxicity of essential oils from Ocimum gratissimum (Lamiaceae) and Laurus nobilis (Lauraceae) from Georgia against the rust-red flour beetle (Tribolium castaneum Herbst) (Coleoptera : Tenebrionidae). Advances in Stored Product Protect, 749-762.

Baraka, D.M. and El-Hady, A.F. (1993). Comparative study of seed lipid constitutents of four species of family Faraceae. Egypt. J. App. Sci., 8 (3): 44-49.

Ben Jemâa, J. M.; Tersim, N.; and Khouja, M. L. (2011). Composition and repellent efficacy of essential oil from Laurus nobilis against adults of the Cigarette Beetle Lasioderma serricorne (Coleoptera: Anobiidae). Tunisian J. Plant Protect, 6(1): 29-42.

Bouda, H.; Tapondjou, L.A.; Fontem, D.A. and Gumedzoe, M.Y.D. (2001). Effect of essential oils from leaves of Ageratum conyzoides, Lantana camara and Chromolaena odorataon on the mortality of Sitophilus zeamais (Coleoptera, Curculionidae). J. Stored Prod. Res., 32 (2): 153-164.

Bream, A.S.; Ghoneim, K.S.; Tanani, M.A. and Nassar, M.M. (2001). Respiratory metabolic risponsiveness, during the pupal stage of the red palm weevil to certain plant exeracts. Med. Fac. Landbouww. Univ. Gent. 66 (2): 491-502.

Dongre, T.K. and Rahalkar, G.W. (1982). Effect of Blumea eriantha (Compositae) oil on reporduction in Earias vittella (F.) Experientia V.,38: 98-99.

El-Bermawy, S.M. and Abdel Fattah, H. M. (2000). Changes in protein electrophoretic pattern of Tribolium confusum $4^{\text {th }}$ instar larvae after treatment with volatile plant oil (Vetiver). J. Egypt. Ger. Soc. Zool., 31: 167-182.

El-Bokl M.M.; Sallam A.M.; Abdallah G.A.; and Gabr B.M.; (2015). Efficay of aggregation pheromone in trapping red palm weevil (Rhynchophorus ferrugenious Olivier) infested Date palms in Damietta, Egypt. Egypt. Acad. J. Biolog. Sci .7 (1) 51-59.

El-Sayed, F.M.A.; Etman, A.A. and AbdelRazik, M. (1989). Effectiveness of natural oils in protecting some stored products from two stored product pests. Bull. Fac. Agric.,Cairo Univ., 40 (2): 409-418.

Farman-Khansaa, S. (2009).The repellancy effect of powder of many plants on red flour beetles Tribolium castanium. Dialy Agric. Sci. J., 1 (2): 18-24.

Finney, D.J. (1952). Probit analysis: a statistical treatment of the sigmoid response curves. $2^{\text {nd }}$ ed. Cambridge Univ. Press.

Frik, L.P. and Nazirov, Z.N. (1981). Components of Euphorbia jaxaritica. C.F. Chem. Abst., 95 (9): 3467. 
Gujar, G.T. and Mehrotra, K.N. (1983). Juvenilizing effect of azadirachtin on noctuid moth, Sopodoptera litura Fabr. Indian J. Exp. Biol., 21: 292293.

Harborne, J.B. (1984): Phytochemical Methods, Second Edition, pp (150-160). Edited by Chapman \& Hall. London, New York.

Huseyin, C.; Ilker, C.; Atila, Y. and Mustafa, G. (2006).Larvicidal activity of some labiatae (Lamiaceae) plant extracts from Turkey, Phytother Res., 20(12): 1088-1090.

Hussein, K.T. (1995). Effect of some plant extracts in the control of a non-biting Muscoid fly. Ph.D. Thesis, Fac. Sci., Zag. Univ., Egypt.

Hussein, K.T. and Shoukry, I.F. (1997). Toxicological and histopathological studies of certain plant fixed oils on Culex pipiens larvae. Ain Shams Sci. Bull., 35: 287-305.

Isikber, A. A.; Alma, M. H.; Kanat, M. and Karci, A.(2006). Fumigant toxicity of essential oils from Laurus nobilis and Rosmarinus officinalis against all life stages of Tribolium confusum. Springer link. Phytoparasitica, 34(2): 167-177.

Jood, S.; Kapoor, A.C. and Singh, R. (1993). Evaluation of some plant parts against Trogoderma granarium Everts. In stored wheat and their effect on nutritional composition and organoleptic characteristics of treated grains.Int. J. pest.Mang., 39 (1): 93-98.

Karahroodi- Zahra, R.; Moharramipour, S.;Farazmand, H.; Karimzadeh-Esfahani, J. (2008). Effect of eighteen plant essential oils on nutritional indices of larvae Plodia interpunctella Hubner (Lep.,Pyralidae). Entomol. J. Res. Islamic Azad Univ., Arak Branch, 1 (3): 209-219.

Karahroodi- Zahra, R.;Moharramipour, S.;Farazmand, H. and Karimzadeh-Esfahani, J. (2011). Insecticidal effect of six native medicinal plants essential oil on Indian meal moth, Plodia interpunctella Hübner (Lep.: Pyralidae). Munis Entomol and Zool., 6(1): 339-345.

Karahroodi- Zahra, R.; Moharramipour, S.; Rahbarpour, A. (2009). Original articlesinvestigated repellency effect of some essential oils of 17 native medicinal plants onadults Plodia interpunctella. American-Euras J. of Sus- tainable Agric., 3(2): 181184.

Khalaf, A.A.; Hussein, K.T. and ShoukryKarima, K. (2009). Biocidal activity of two botanical volatile oils against $\mathrm{t}$ the larvae of Synthesiomyia nudiseta (Wulp) (Diptera: Muscidae). Egypt. Acad. J. boil. Sci., 2(1): 89-101.

Kotan R., S. Kordali A. Cadir, M. Kesdek, Y. Kaya, H. Kilic. (2008).Antimicrobial and insecticidal activities of essential oil isolated from Turkish Salvia hydrangea DC. ex Benth. Biochemical Systematic and Ecology, 36: 360-368.
Koul O., S. Walial, G. S. Dhaliwal. (2008). Essential oils as green pesticides: Potential and Constraints. Biopesticides international, 4(1): 63-84.

Kweka, E.J.; Senthilkumar, A and Venkatesalu, V. (2012). Toxicity of essential oil from Indian borage on the larvae of the African malaria vector mosquito, Anopheles gambiae. Parasites \& Vectors J., 277(5):15 .

LEE B. H., W. S. Choi, S. E. LEE, B. S. Park.(2001) . Fumigant toxicity of essential oils and their constituent compounds towards the rice weevil, Sitophilus oryzae (L.) . Corp protection, 20: 317-320.

Mohamad, A.H.; Obadi, A.K. and Ramdan, F.M. (2011). Attraction, repellency and toxic effect of some plant extracts on the Southern cowpea weevil Callosobruchus maculates (Fab.) (Coleoptera : Bruchidae). Tekrit Agric. Sci. J. 11 (2): 204-209.

Moustafa, S.M.; Kadry, H.A.; El-Olemy, M.M. and and Bisher, M.M. (1986). Lipids, pigments and saponines of Sansevieria cylindrica, Bjor. Bull. Pharm. Sci., Assuit. Univ., 9 (1): 1.

Mostafa, Z.K.; El-Sherif, L.S. and Hewady, M.A.A. (1995). Effect of certain volatile plant oils on the activity of malate dehydrogenase and malic enzyme in Pectinophora gossypiella (Saun.) and Earias insulana (Boisd) larvae (Lepidoptera: Noctuidae). J. Egypt. Ger. Soc. Zool., 17: 13-23.

Nassar, M.I. (1995). The potential of some juvenoids precocenes and botanical extracts for the control of Muscina stabulans (Fallin), Ph.D. Thesis, Fac. Sci. Cairo University, Egypt.

Nassar, M.I. and Abdullah, A.M. (2005). Assessement of Boxus chinensis oil and Precocene II for the control of the red palm weevil, Rhynchophorus ferrugineus (Oliver) (Coleoptera-Curculionidae) and the palm beetle Pseudophilus testsceous (Gahan) (Coleoptera-Cerambycidae). J. Entomol., 2(1): 1-8.

Nassar, M.M. and Abdullah, A.A. (2001). Evaluation of Azadirachtin for control of the red palm weevil Rhynchophorus ferrugineus (Oliver). J. Egypt. Ger. Soc. Zool. Entomol., 36: 163-173.

Regnault-Roger, C. (1997). The potential of botanical essential oils for insect pest control; Integrated Pest Management Reviews, (2): 25-34.

Regnault-Roger, C. and Hamraoui, A. (1995). Comparison of the insecticidal effects of water extracted and intact aromatic plants on Acanthoscelides obtectus, a bruchid beetle pest of kidney beans. Springer link. Chemoecology, 5-6 (1): 15 .

Saleh, M.R.A. (1992). Red palm weevil, Rhynchophorus ferruginous (Oliver) in the first record for Egypt and indeed the African continent list No: 10634 Africa collection No. International Institute of Entomol., 56Queen5 gate. London, Sw., 75 JR.UK.

Schoonhoven, A.V. (1978). Use of vegetable oils to protect stored beans from Bruchid attack. J. Econ. Entomol., 71 (2): 254-256. 
Shaaya, E.; Kostjukovski, M.; Eilberg, J. and Sukprakarn, C. (1997). Plant oils as fumigants and contact insecticides for the control of stored-product insects. J. Stored-Prod. Res., 33: 7-15.

Shankaranarayana, K.H.; Shivaramakrishnan, U.R.; Ayyar, K.S. and Sarma, P.A. (1979). Isolation of a compound from the barch of sandal Santhalum album (L.) and its activity against some lepidopterous and coleopterous insects. J. Entomol. Res., 3 (1): 116118.

Shoukry-Karima, K. (2003). Toxicological effects of botanical extracts against some stored product insects. .M.Sc. Thesis, Fac. Sci. Zagazig Univ.

Singh, D.; Siddiqui, M.S. and Sharma, S. (1989). Reproductive retardant and fumigant properties in essential oils against rice weevil (Coleoptera: Curculionidae) in stored wheat. J. Econ. Entomol., 82(3): 227-233.

Singh, S.R.; Luse, R.A.; Leuschner, K. and Nangtu (1978). Groundnut oil treatment for the control of Callosobruchus maculatus (F.). J. Stored Prod. Res., 14: 77-80.
Sun, Y. P. (1950). Toxicity index: an improved method of comparing the relative toxicity of insecticides. J. Econ. Entomol., 43: 45-53.

Swidan, M.H. (1996). Effectiveness of some vegetable oils in protecting blackeyed peas from the attack of cowpea weevils, Callosobruchus maculates F. (Coleoptera: Bruchidae). J.Egypt. Ger. Soc. Zool., 19: 29-39.

Taheya, S.M. and Al-Moagel, N.H. (1993). Grain insect control agent from tumeric (Curcuma longa L.) rhizome extract. J. Egypt. Ger. Soc. Zool., 12: 111-130.

Tayoub, G.; Odeh, A. and Ghanem, I. (2012). Chemical composition and fumigation toxicity of Laurus nobilis L. and Salvia officinalis L. essential oils on larvae of khapra beetle (Trogoderma granarium Everts). Herba Polonica, 58(2): 26-37. 